\title{
Women Participation in Community-based Rural Tourism Development in North Minahasa Regency
}

\author{
Jolanda Esther Kaihatu' ${ }^{1}$, Marjono ${ }^{2}$, Gatot Ciptadi $^{3}$, Andi Kurniawan ${ }^{4}$ \\ \{jolandaekaihatu@gmail.com ${ }^{1}$ \} \\ Universitas Negeri Manado, Indonesia ${ }^{1}$ \\ Universitas Brawijaya, Indonesia ${ }^{2,3,4}$
}

\begin{abstract}
Rural Tourism Program provides opportunities for women as entrepreneurs. Women as business people can contribute income to households. The problem examined concerns what internal factors are related to the women participation as entrepreneurs in the rural tourism development. This study aims to identify, describe and analyze the internal factors of women participation as entrepreneurs in the rural tourism development. This research uses quantitative approach that is supported by qualitative data. The results showed that women age, education level, business length had large contribution with women participation as entrepreneurs in rural tourism development. Thus, the greater women participation as entrepreneurs in rural tourism development, the higher their contribution to household income.
\end{abstract}

Keywords: Rural Tourism, Women Participation, Entrepreneurs.

\section{Introduction}

The creation of a community based rural tourism area in line with government principles in sustainable development. Development requires community participation, both men and women. Law Number 17 of 2007 concerning the long-term development plan 2005-2025 stipulates that the vision of national development is to make Indonesia independent, developed, just and prosperous. The word just gives the meaning of equal rights between men and women in managing an activity in the community that impact on development, such as the rural tourism development. In fact, gender equality has not yet been fully focused on development. This is supported by data from the Ministry of Women Empowerment and Child Protection [1], which shows the high value of Indonesia gender inequality index, which is 0.5 which occupies the third position in the ASEAN countries after Laos and Cambodia. More clearly this is shown by the still high gender inequality between women and men in the fields of health, education, and economy.

The rural tourism program has been promoted since 2009 by the Ministry of tourism through the assistance of the PNPM Independent Tourism. Rural Tourism plays major role in boosting tourism. The rural tourism development will encourage productive economy carried out by the local community. The rural tourism development based on the local community requires the care and participation of men and women to constantly innovate and be creative in developing their village areas which are made as rural tourism [2]. States that working women has great potential in supporting their family's economy. Therefore, there is need for the women participation analysis as entrepreneurs in community-based rural tourism. Women can 
participate in the rural tourism development through culinary business activities, souvenir making and tourism activities or activities carried out in tourism area.

Marinsow Village is one of the potential tourism destinations to be developed into rural tourism. Located in the East Likupang Sub District, North Minahasa Regency, North Sulawesi Province. The hilly topography and the lowlands make different villages provide different colors of community activities from economic, social and cultural aspects. This village has potential tourism objects that are worth selling and preserving such as beautiful pall beach tours in the shape of a crescent moon, enjoying sunrise and sunset, various kinds of beach activities. Community life, mutual assistance, friendly, simple life, mostly as farmers and fishermen, characterizes a rural tourism that is well developed and preserved. In Marinsow, the number of business operators is 40 , consisting of 30 women and 10 men. The involvement of women in tourism activities will have obstacles that affect the women participation both from themselves and from the surrounding environment. This is interesting reason to research. Based on the potential and reality in the field, the problem is formulated as what internal factors that are related to the women participation as business actors in the rural tourism development in Marinsow village, North Minahasa Regency? Research goals analyzing internal factors related to women participation as business actors in the rural tourism development in Marinsow Village, North Sumatra Regency.

\section{Theoretical Framework}

Rural Tourism is a form of integration between attractions, accommodation and supporting facilities that are presented in structure of community life that integrates with the applicable procedures and traditions. One form of rural tourism development is through the concept of Community Based Tourism (CBT) [3].

The success of the Rural tourism can be measured by how much the participation of the community/villagers, where all village residents are involved, namely the father of the mother, housewife, youth and children as well as village officials. Establishing tourism awareness the key is innovation [4].

Tourism strategies using the 4A method, namely: a) Attraction. Attraction is the main product of destination. Attractions are related to what to see and what to do. What can be seen and done by tourists in these destinations. b) Accessibility. Accessibility is a means and infrastructure to get to the destination. c) Amenity. Amenities are all supporting facilities that can meet the needs and desires of tourists while in the destination. d) Ancillary. Relating to the availability of the organization or people who manage the destination [5].

According to Cohen \& Uphoff [6], the concept of participation is the community participation in the process of implementing, utilizing results, planning, and making decisions. The concept is also participation stage as follows: a). Decision making stage; this stage is encouraged by the participation of the community in meetings. The decision-making stage is intended to be in the planning and implementation of program. b) Implementation stage; the most important stage in development, because the core of development is its implementation. The actual nature of participation at this stage is classified into three, namely participation in the form of thought contributions, material contribution forms, and actions as project members. c) Evaluation stage; this stage is considered important because community participation at this stage is feedback that can provide input for the improvement of subsequent project implementation. d) The stage of enjoying results; this stage can be used as 
an indicator of the success of community participation at the project planning and implementation stages. Besides seeing the community's position as the subject of development, the greater the project benefits are felt, meaning that the project has succeeded in achieving its goals.

Factors that influence community participation can be distinguished in internal factors and external factors. Internal factors according to Slamet [7], Internal factors are derived from within the community itself, namely the individual and the group unity within it. Individual behavior is closely related or determined by sociological characteristics such as age, sex, knowledge, occupation, and income. Theoretically, there is relationship between individual traits and participation level, such as age level of education, type of work or length of business, duration of community membership, income, involvement in development activities will affect participation. Thus, tourism development planning must accommodate the desires and abilities of local communities to participate and obtain maximum value from the development of tourism. Local community participation is needed in the rural tourism development because local people as owners of tourism resources are sold to tourists.

\section{Research Methods}

This research uses quantitative approach supplemented with qualitative data. Quantitative approaches are carried out using the census method. A qualitative approach is used to analyze number percentage women participation as entrepreneurs in rural tourism and their contribution to household income. The population used to carry out the census method is women as culinary entrepreneurs, souvenirs and other tourism activities. This study uses qualitative data as supporting arguments namely in-depth interviews using guide questions, observations, and related documentation studies. Data analysis is presented in the frequency table and described. This research was conducted in Marinsow village, East Likupang subdistrict, North Minahasa regency, North Sulawesi Province. The selection of research sites is based on the following consideration: a) It is tourism development area in Eastern Indonesia, b) It has unique tourism potential and different from the others, c) It has high accessibility, and d) It is very good to be used as rural tourism.

\section{Results and Discussion}

Marinsow Village, East Likupang Subdistrict, Minahasa Regency, North Sulawesi Province, is about $29 \mathrm{~km}$ from Manado, North Sulawesi Province. There are 10 villages located on the coast, 4 villages on the mainland, and 4 villages on Bangka Island. The boundaries are as follows: North: Bordered by the sea of Sulawesi, East: bordered by the city of Bitung, South: Bordered by South Likupang Subdistrict, West: Bordered by West likupang sub-district. The administrative boundary of Marinsow Village is North bordering Pulisan Village, South bordering Kalinaun Village and Rinondoran Village, West bordering Maen Village and Wineru Village, East bordering the Maluku Sea. The topography is rough or hilly. Accessibility conditions can be seen from the transportation network, travel time and road conditions.

The total population of Marinsow Village is 689 people, with varying levels of education from junior high school, academics, SI, S2, and are still classified as very low. Livelihoods 
66.66 percent as farmers and most people live from farming. Marinsow Rural Tourism Object, Beach Tourism known as Pall Beach was officially opened on 09 February 2015 by the Government of Marinsow Village. The mutual cooperation community, friendly, most of them are farmers with simple life, most are Christian, and friendly community in welcoming the newcomers.

Culinary business economic activities and tourist activities such as the business of renting cottage, banana boat, beach umbrellas and young coconut snacks are carried out by mothers. Culinary business is carried out by mothers and is assisted by their families because this business is their own. The distinctive feature of this culinary tour is package of very fresh vegetable fish completed with orange chili sauce.

This research was conducted in Marinsow Village with 30 female respondents as entrepreneurs. Women as entrepreneurs have internal factors as individual characteristics in participation such as women age, women last education level, and the length of their business. The following discussion will discuss the number and percentage of internal factors for women participation as entrepreneurs in table 1.

Table 1. Number and Percentage by Category of Age, Education Level, and length of business in Marinsow Village in 2019

\begin{tabular}{lcc}
\multicolumn{1}{c}{ Internal Factor } & Amount (n) & Percentage (\%) \\
\hline 1. Age & 12 & 40 \\
Young adult (20-40) & 18 & 60 \\
Middle adult (41-64 years old) & 0 & 0 \\
Older adult (65 years and over) & 30 & 100 \\
Total & & \\
\hline 2. Education level & 7 & 23.33 \\
Low (Not graduated/Elementary school) & 6 & 20 \\
Middle (Junior High School) & 17 & 56.67 \\
High (Senior high school/ university) & 30 & 100 \\
Total & & 0 \\
\hline 3. Length of business & 0 & 26.67 \\
Low (<2 years) & 8 & 73.33 \\
Middle (2-5 years) & 22 & 100 \\
High ( $>$ 5 years) & 30 & \\
Total & & \\
\hline
\end{tabular}

Source: Primary data and analysis result, 2019.

\subsection{Women Age}

The age of the respondents is in the middle adult age category (41-64) with a percentage of 60 percent. In the middle adulthood level is the age to live a mature family life, maintain social groups, and maintain economic life. 12 women are in young adulthood. Thus, women still have a lot of time and energy to carry out social activities outside of other activities.

\subsection{Women Education Level}

The level of formal education is largely classified as high graduated from senior high school/college 56.7 percent. Shows that respondents who have been in formal education for more than 9 years usually come from families who are economically capable, for those who 
have not graduated from elementary school / graduated from elementary school are caused by economic limitations and help families earn money. Women also have the right to continue their education to higher level.

\subsection{Length of Women Business}

Women who have been in business in an area will be easy to exploit the existing potential and have solution to the problems faced. The length of women business in the village of Marinsow has been in the business for more than 5 years, as many as 22 women $(73.33 \%)$. Women as entrepreneurs mostly use natural resources available for raw materials for culinary business production. Raw materials such as fresh fish directly taken from the sea, water spinach, bananas, young coconut, papaya and so forth.

\section{Conclusions and Recommendations}

Based on the results of observational studies, in-depth interviews and as well as literature studies then make frequency table and analyze based on internal factors variables of women as business actors, the following conclusions are drawn: Based on Women Age, The category of middle-aged adults (41-64) with a percentage of 60 percent. In the middle adulthood level is the age to live mature family life, maintain social groups, and maintain economic life. 12 women are in young adulthood. Thus, women still have lot of time and energy to carry out social activities outside of other activities. Based on Women Education Level, the level of formal education is largely classified as high that graduated from high school/college 56.7 percent. Shows that respondents who have been in formal education for more than 9 years usually come from families who are economically capable, for those who have not graduated from elementary school/graduated from elementary school are caused by economic limitations and help families earn money. Women also have the right to continue their education to a higher level. Based on the Length of Women Business, Women who have been in business in an area will be easy to exploit the existing potential and have a solution to the problems faced. The length of women business in the village of Marinsow has been in the business for more than 5 years, as many as 22 women $(73.33 \%)$. Women as entrepreneurs mostly use natural resources available for raw materials for culinary business production. Raw materials such as fresh fish directly taken from the sea, water spinach, bananas, young coconut, papaya and so forth.

\subsection{Recommendation}

a) It takes a strong commitment from the government especially the North Minahasa Regency Government in the community-based Rural tourism development in terms of empowering women in supporting Regional tourism.

b) It is necessary to intensify training and intensive human resource training for rural communities and women as entrepreneurs in the tourism sector, so that it is expected to be able to encourage the success of improving the quality of visitors in Marinsow Village.

c) Infrastructure and facilities need to be improved and the cleanliness of tourism attractions and the community environment should be improved so that beautiful, cool, friendly and environmentally friendly village can be realized. 


\section{References}

[1] Ministry of Women Empowerment and Child Protection (KPPA), Gender-Based Human Development 2015. Jakarta: Ministry of Women Empowerment and Child Protection, 2015.

[2] Farida, "Contribution of Informal Sector Working Income to the Family Economy," J. Bus. Appl., vol. 01, no. 02, pp. 103-112, 2011.

[3] W. Dedi, "Rural tourism," Wikipedia, 2009.

[4] Justanother, "Rural tourism Development Steps and Strategies," Wordpress, 2009. .

[5] K. HT, S. S, and V. L, Marine Tourism Object Development in East Likupang (Case Study, Pulisan Beach). Manado: UNSRAT Research Report.

[6] J. M. Cohen and N. T. Uphoff, "Participation's Place in Rural Development: Seeking Clarity Through Specificity," 1979 . .

[7] M. Slamet, Participatory Insightful Community Development. Surakarta, 2003. 